\title{
Examinations of the stomach contents of two fish species (Clarias gariepinus and Oreochromis niloticus) in Lake Alau, North - Eastern Nigeria
}

\author{
Umaru Buba Wakil ${ }^{1}$, A. B. Haruna, ", Gwana Adamu Mohammed ${ }^{3}$, Wanas Lalai Ndirmbita ${ }^{1}$, \\ Bukar-Kolo M. Yachilla ${ }^{4}$, Mohammed Umar Kumai ${ }^{5}$ \\ ${ }^{1}$ Department of Fisheries, Faculty of Agriculture, Unimaid, Nigeria \\ ${ }^{2}$ Department of Fisheries, Faculty of Agriculture, Kogi State University, Eyimgba, Kogi State, Nigeria \\ ${ }^{3}$ Laboratory Unit, Department of Animal Health and Production, Mohamet Lawan College of Agriculture, P.M.B. 1427, Maiduguri, Nigeria \\ ${ }^{4}$ Department of Medicine, Faculty of Veterinary Medicine, Unimaid, Nigeria \\ ${ }^{5}$ Department of Agricultural Technology, Mohamet Lawan College of Agriculture, P.M.B. 1427, Maiduguri, Nigeria
}

\section{Email address:}

ubwakilgza@yahoo.com (Umaru B. W.), admuwana@yahoo.com (Gwana A. M.), lalaindirmbita@gmail.com (Wanas L. N.), yachillabukar@yahoo.com (Bukar-Kolo M. Y.), mohammedumarkumai@gmail.com (Mohammed U. K.)

\section{To cite this article:}

Umaru Buba Wakil, A. B. Haruna, Gwana Adamu Mohammed, Wanas Lalai Ndirmbita, Bukar-Kolo M. Yachilla, Mohammed Umar Kumai. Examinations of the Stomach Contents of Two Fish Species (Clarias Gariepinus and Oreochromis Niloticus) in Lake Alau, North - Eastern Nigeria. Agriculture, Forestry and Fisheries. Vol. 3, No. 5, 2014, pp. 405-409. doi: 10.11648/j.aff.20140305.23

\begin{abstract}
This study was conducted on the examinations of the stomach contents of two commercially important fish species of Catfish and Tilapia fish (Clarias gariepinus and Oreochromis niloticus) known as "Tarwada" and "Karfasa" in Hausa language, determined from Lake Alau, North - Eastern Nigeria, using frequency of occurrence and volumetric methods between June to December, 2013. Gill nets and Malian traps were used to catch the fish every fortnight. Three hundred and fifty (350) individual fish of each species obtained and their stomach contents examined. The results obtained expressed in mean percentage indicated that out of the three hundred and fifty (350) individual fish of each species examined, $121(35 \%)$ fish had an empty stomach contents in Clarias gariepinus, and out of the 350 samples examined, 145 fish had an empty stomach content in Oreochromis niloticus representing $41 \%$. The stomach contents of Clarias gariepinus consisted of animal and plant materials, planktons, (zooplanktons and phytoplankton) and others. Fish prey was the dominant animal material (51\%) with mean contribution of $32 \%$ by volume, and plant material consisted of leaves and offal ( $6 \%$ by volume). The stomach content of Oreochromis niloticus consisted mainly of animal and plant materials, planktons and detritus. Algae represented by Chlorella, Volvox, Scenedesmus, Pediastrum, and Spirogyra species accounted for $66 \%$ by volume followed by detritus and mud with $20 \%$, zooplankton represented by Daphnia and Moina species represented the low food content by volume with $8 \%$. The study reveals the importance of algae, fish, insects and plant materials as food for fish in Lake Alau, and zooplanktons form important items in the diet of the species examined. Both species are omnivorous and occupy the same ecological niche; hence, there is the need to control pollution into the lake to prevent eutrophication.
\end{abstract}

Keywords: Clarias Gariepinus, Frequency Analysis, Oreochromis Niloticus, Stomach Contents, Volumetric Analysis, Lake Alau

\section{Introduction}

Fishes are sources of food for human beings and other animals, rich in proteins and vitamins, especially, vitamin A (Retinol). Thus, they are source of animal protein. Fishes such as those in the class families, Clariidae and Cichlidae are highly used and commercialized. The Commercially important fish species in these class families are the Catfish and Tilapia fish (Clarias gariepinus and Oreochromis niloticus) known as "Tarwada" and "Karfasa" in Hausa language. All fish require energy for growth, reproduction and migration, which must be obtained from its food sources $[3,19,24]$. Understanding food and feeding habits of fish is useful to all scientists who are concerned with any aspect of fisheries [11]. Royle (2001) reported that potential food 
resources of fish consist of all materials present in its environment. Fishes have been known to feed on a wide variety of items ranging from Sand particles, phytoplankton, zooplanktons, leaves, roots, crustaceans, insects, insect larvae, worms, fishes e.t.c, $[17,18,22]$. According to David et. al, (2010) and Munro (2001) fishes in temperate climate are seasonal in their feeding which is caused by a combination of factors. The amount of feed required in warm water conditions is higher than that in cold water because, at lower temperatures digestion and metabolic are slowed down $[10,20]$. Lake Alau is among the numerous small reservoirs and the second largest lake in Borno state, North - Eastern Nigeria. Bankole et. al, (2003) reported on the diversity, abundance and distribution of fish species in the lake and identified ten fish species belonging to eight families with annual fish catch from 471.1 metric tons at low water level to 584.9 metric tons at high water level. Among the commercially important species are; Oreochromis niloticus, Clarias gariepinus, Tilapia zilli, Schlibe intermedius Mormyrus rume, Brycinius nurse, Heterotis niloticus, Hemichromis bimaculatus, Hemichromis fasviatus, Labeus sp, Protopterus annectus and Synodontis spp. These species are economically exploited for food and ornamental purpose [15] In Lake Alau, Clarias gariepinus (Clariidae families) Catfish and Oreochromis niloticus (Cichlidae families) Tilapia fish are highly priced fishes of considerable economic importance and available throughout the year and widely distributed [2]. Clarias gariepinus is a benthopelagic fish with a wide range of diet $[1,8,10,22,23]$. According to Yalcin et al. (2002), cichlids are among the most commercially exploited fishes for human consumption especially in African lakes. The major food items of Oreochromis niloticus are mainly macrophytes, green algae, detritus, sand grains, insect parts, e.t.c, $[1,8,16,23]$. Various works have been done on the diets of Clarias, Oreochromis, and other fish species from various lakes in Nigeria and few other lakes and reservoirs. These studies provide useful information on the trophic relationships in aquatic ecosystems and biodiversity, and also used in formulating management strategy options in a multi species fishery. In Lake Alau, little or no extensive work has been carried out on the stomach content of commercial importance species. Therefore, this study investigates the stomach contents of Catfish (Clarias gariepinus) and Tilapia fish (Oreochromis niloticus) in order to ascertain the types of food content consumed by the said fish species in Lake Alau, North Eastern Nigeria.

\section{Methodology}

\subsection{Study Area and Location}

Lake Alau is a freshwater lake in North - Eastern Nigeria. It is $19 \mathrm{~km}$ south - east of Maiduguri, the capital city of Borno state. It is located between latitude $10^{\circ} 43^{1} \mathrm{~N}$ and Latitude $10^{\circ} 15 \mathrm{E}$ and $13^{\circ} 17 \mathrm{E}^{\circ}[5]$. It has a total surface area of $56 \mathrm{~km}$ with two distinct seasons; a rainy season with mean annual rainfall of $600 \mathrm{~mm}$ for July to October and a hot dry season from March to July, the dry season is preceded by a period of harmattan (a dusty, dried, cool and windy breeze blown from the Sahara desert from North Africa) between Novembers to February [3]. It has a relative humidity of $49 \%$ with temperature range of $28^{\circ} \mathrm{C}$ to $46^{\circ} \mathrm{C}$ for both seasons. It has a maximum storage capacity of 54,600ha [6]. Five landing sites were selected based on certain factors such as accessibility to the area, security and fishing activities. These stations are Abari fishing community, Daban Ali Zaki, automatic spillway, Gada and Musari landing sites respectively.

\subsection{Materials}

\subsubsection{Apparatus Used}

Gill nets and Malian traps, scissors, sharp knives, mat, bowl, metre rule, dissecting kits, absorbable cotton wool, hand towels, safety and protection wears, Electrical binocular microscope and large mouth screw cap containers.

\subsubsection{Reagents Used}

$4 \%$ formalin solution, $75 \%$ alcohol solution, hypochlorite solution, dusting powder, detergent, soap and tap water.

\subsection{Method}

\subsubsection{Sample Collection}

Three hundred and fifty (350) individual fish of each species were caught with gill nets and Malian trap biweekly between Junes to October, 2013. Captured fish were sorted into different species and sizes. The total length of each fish was measured and noted to the nearest centimeter, each fish with regardless to sex, was dissected and the gut content was removed, transferred to the container and preserved in $4 \%$ formalin fixative, and transported to Laboratory immediately.

\subsubsection{Method}

In the laboratory, the benches were cleaned and disinfected with hypochlorite solution. The specimen containers were brought and laid down on to the clean and disinfected benches. The stomach contents were emptied into Petri dish and each food item was counted under objective lens of x 60 magnification power of an electrical binocular microscope. The gut contents were analyzed using frequency of occurrence and volumetric methods based on Hynes (1950). In the frequency of occurrence method, the occurrence of food items was expressed as the percentage of the total number of stomach containing food, while in volumetric method; percentage volume contribution of each food items was visually assessed relative to the entire food item present in the gut estimated.

\subsection{Data Analysis}

Data obtained were subjected to simple statistical tools of analysis by using percentage, mean and standard deviation in order to ascertain the significance of the variables obtained, as described by Stroud and Booth, (2001) and as performed by Gwana et. al, (2014). 


\section{Results and Discussion}

\subsection{Results}

The percentages of empty stomachs are shown in Tables 1 and 3. Three hundred and fifty (350) samples, each of Clarias gariepinus and Oreochromis niloticus were examined from June to December covering two seasons in Lake Alau. One hundred and twenty one (121) had empty stomach contents in Clarias gariepinus is representing $34.57 \%$. In Oreochromis niloticus out of 350 samples examined, one hundred and thirty four (134) had an empty stomach, representing $38.29 \%$ respectively.

Table 1. Analysis of stomach content of Clarias gariepinus from Lake Alau

\begin{tabular}{llll}
\hline Periods of Months & Number of Stomach Examined. & Number of Empty Stomach & Percentage of Empty Stomach \\
\hline June & 50 & 17 & 34 \\
July & 50 & 22 & 44 \\
August & 50 & 9 & 18 \\
September & 50 & 32 & 64 \\
October & 50 & 13 & 26 \\
November & 50 & 12 & 24 \\
December & 50 & 16 & 32 \\
Total (Mean \pm STDev) & $350(50 \pm 0)$ & $121(17 \pm 8)$ & $242(35 \pm 15)$ \\
\hline
\end{tabular}

Table 2. Summary of the percentages of food items of Clarias gariepinus in Lake Alau

\begin{tabular}{|c|c|c|c|}
\hline \multirow{2}{*}{ Type of food Materials. } & \multirow{2}{*}{ Type of Food. } & \multicolumn{2}{|l|}{ Parameters in percentage } \\
\hline & & Frequency of occurrence & Volume \\
\hline \multicolumn{4}{|l|}{ Animal's } \\
\hline & Insects / insects larvae & 17.25 & 10.8 \\
\hline & Fish prey and remains & 51.75 & 32.4 \\
\hline Total $($ mean \pm StDev) & & $69(35 \pm 24)$ & $43.2(22 \pm 15)$ \\
\hline \multicolumn{4}{|l|}{ Plant's } \\
\hline & Leaves & 30 & 4.65 \\
\hline & Offal & 10 & 1.55 \\
\hline \multirow{5}{*}{$\begin{array}{l}\text { Total (mean } \pm \text { StDev) } \\
\text { Zooplankton's }\end{array}$} & & $40(20 \pm 14)$ & $6.2(3 \pm 2)$ \\
\hline & & & \\
\hline & Copepod & 20 & 9.6 \\
\hline & Branchions species & 5 & 2.4 \\
\hline & Rotifera species & 5 & 6.8 \\
\hline \multirow{3}{*}{$\begin{array}{l}\text { Total }(\text { mean } \pm \text { StDev }) \\
\text { Phytoplankton's }\end{array}$} & & $40(10 \pm 9)$ & $17.8(6 \pm 4$ \\
\hline & & & \\
\hline & Blue algae / green algae & 19 & 27.44 \\
\hline \multirow{3}{*}{$\begin{array}{l}\text { Total }(\text { mean } \pm \text { StDev }) \\
\text { Other's }\end{array}$} & & $19(0 \pm 0)$ & $27.44(0 \pm 0)$ \\
\hline & & & \\
\hline & Sand and mud detrus & 20 & 4.1 \\
\hline Total (mean \pm StDev) & & $20(0 \pm 0)$ & $4.1(0 \pm 0)$ \\
\hline
\end{tabular}

As shown in table 2, the stomach contents of Clarias gariepinus in Lake Alau consisted mainly of animal materials, plants materials, planktons, (zooplanktons and phytoplankton) and other. Animal's material, fish in particular was the dominant prey 51.75 with a mean contribution of $32.4 \%$ by volume and plants materials consists of leaves and offal contributed 6.2 by volume. Other important components of the diet of the species were phytoplankton mainly blue and green algae, these food items contributed $27.44 \%$ of the diet by volume.

While zooplanktons were made up of Copepods, Cyclops and Rotifera contributed $19.16 \%$ of the diet by volume. Other food items in stomach of Clarias gariepinus are sand, mud and detritus, which contributed $4.1 \%$ by volume. The summary of stomach contents in Oreochromis niloticus are presented in table 4 . The stomach content of Oreochromis niloticus consists mainly of animal and plant materials, planktons and detritus, Algae represented by Chlorella, Volvox, Scenedesmus, Pediastrum and Spirogyra species accounted for $65.8 \%$ by volume followed by detritus / mud with $20.2 \%$ zooplankton represented by daphnia and moina species recorded the low food content by volume with $7.7 \%$.

Table 3. Analysis of stomach content of Oreochromis niloticus in Lake Alau

\begin{tabular}{llll}
\hline Periods of Months & Number of stomach examined & Number of empty stomach & Percentage of empty stomach \\
\hline June & 50 & 6 & 12 \\
July & 50 & 18 & 36 \\
August & 50 & 11 & 22 \\
September & 50 & 21 & 42 \\
October & 50 & 33 & 66 \\
November & 50 & 24 & 48 \\
December & 50 & 32 & 64 \\
Total (Mean \pm STDev) & $350(50 \pm 0)$ & $145(21 \pm 10)$ & $290(41 \pm 20)$ \\
\hline
\end{tabular}


Table 4. Summary of the percentage of food items of Oreochromis niloticus in Lake Alau

\begin{tabular}{llll}
\hline Type of food Materials. & Type of Food. & Parameters in percentage & \\
\cline { 3 - 4 } & Frequency of occurrence & Volume \\
\hline Animal's & insects larvae & 3.0 & 2.0 \\
Total (mean \pm StDev) & & $3(0 \pm 0)$ & $2(0 \pm 0)$ \\
Plant's & & 4.3 \\
Total (mean \pm StDev) & Leaves & 20 & $4.3(0 \pm 0)$ \\
Zooplankton's & & $20(0 \pm 0)$ & 7.7 \\
& Mona micrupa, Daphnia spp & 30 & 20.2 \\
Total (mean \pm StDev) & Detritus $/$ mud /sand grains & 40 & $27.9(14 \pm 9)$ \\
Phytoplankton's (Algae) & & $70(35 \pm 7)$ & 16.3 \\
& & 20 & 15.1 \\
& Chlorella & 18 & 13.2 \\
& Volvax & 15 & 8.0 \\
& Scenedesmus & 9 & 13.2 \\
Total (mean \pm StDev) & Pediostrum & 15 & $65.8(13.2 \pm 3.2)$ \\
\hline
\end{tabular}

\section{Discussion}

The stomach content of Clarias gariepinus in lake Alau indicated that they fed on a wide variety of food items ranging from plants and animals materials and planktons as well as detritus, thus considered as omnivorous, which is in line with the findings and observations made by Burton (1994) who stated that "Clarias gariepinus is considered to be omnivorous displaying both scavenging and predatory behavior." The results obtained in this study showed that the most frequent food components $(64 \%)$ are animal materials (fish / insects larvae). These results agreed essentially with the observation of some authors on Clarias mossambicus inhabiting Lake Victoria, in South Africa that indicated that the Clarias gariepinus did not rely only on offshore fishes and benthic invertebrates at high lake level, but they readily switched their feeding to littoral fishes and invertebrates when these became abundant. Apart from the substantial amount of animal material encountered in the stomach of Clarias gariepinus, high proportions of zooplanktons were consumed by this fish. The use of zooplankton as food by this species in Lake Alau is probably because their wide sub terminal mouth enable them suck in large amounts of water which flushed through the gill for filter feeding. Efficiency of zooplankton capture is ensured by the large number of gill rakers which increase with size.

The Cladocera are favoured over the more abundant copepod as prey by fish predators, with a lot of algae being in Lake Alau. Zaret (1980) and O'Brien (1987) reported that Zooplanktivorous fish often take Cladocerans in preference to copepod, perhaps because, the latter have a more erratic mode of motion and as such, not easy to capture, and it's a fact that it could also explain the results of this study. Oreochromis niloticus exhibited a richer flora and fauna dietary assemblage utilized in throughout the studies period. Shalloof and Khalifa, (2009) reported that, O. niloticus and $S$. galilaeus were observed to be herbivores having highest percentage frequency of occurrence of higher plant remains as 49.2 and $60.3 \%$, respectively. The present study is in agreement with earlier reports for these fish species found in some other water bodies. For instance, O'Brien (1987) noted that interspecific competition occurred among the four cichlid species in Lekki Lagoon. Also, O’Brien (1987) further reported that, these fish species (Oreochromis spp) fed mainly on detritus, insects and plant materials in Ikpoba River. David et al, (2010) observed that the presence of tiny unicuspid teeth in the mouth of the fish suggests that fish species feed on plants, leaves, buds and seeds of water lilies and are thus herbivorous feeders.

The low number of zooplankton in the stomach of Oreochromis niloticus could probably be attributed to turbidity of the lake water during the study period. Omondi et. al., (2011) reported that, turbidity reduces visibility of the predators and on feeding rhythms. Apart from the major food items, they also picked a variety of other food items. Further, stated that, Teleost including cichlids were able to exploit more than one source. This ability to exploit different varieties of food makes $O$. niloticus to be omnivorous. Several other workers have also reported on the high degree of overlap in diet of fishes from the same community.

\section{Conclusions and Recommendations}

\subsection{Conclusion}

This study revealed the importance of algae, fish, and insect and plant materials as food for fish in Lake Alau. It further showed that zooplanktons form important items in the diet of Clarias gariepinus and Oreochromis niloticus. As a result of poor water quantity due to run-off, on the other hand reduce suitable food due to low densities of macro invertebrates. The most frequent food items found in the stomach of African catfish in all the reaches were fish prey and fish remains constituting $64 \%$ of the diet in the wet season and less than $20 \%$ in the dry season. Among the habitual prey; insects, crustaceans, worms and rotifers occur most frequently during the dry season, constituting $40 \%$ of 
the diet, as these species of fish compete on zooplanktons with the fries subjecting them to stunted growth and probably mortality.

\subsection{Recommendations}

Based on the findings of this research, there is the need to reduce siltation into the Lake Alau by stopping soil fillage and planting of soil cover in the catchment of the Lake. This would reduce turbidity in the Lake during early rain full with a result of increased productivity due to increase light penetration. There is also the need to control pollution into the Lake Alau to prevent eutrophication.

\section{Acknowledgement}

It is a great pleasure to acknowledge with most honoured and duly respected; we owe particular thanks to all those researchers and their works cited in this piece of work, and also most grateful to all persons who have helped or assisted in one way or the other in the course of carrying out this study successfully.

\section{References}

[1] Abdel-aziz, N.E and Gharib, S.M. "Food for feeding habits of rund sardinella (sardinellaaurita) in El- mex Bay, Alexandria, Egypt" Egypt: J. Aquat Res.33:202-221. 2007.

[2] Babatunde, D.O., and Aminu, R. "Field guide to Nigeria freshwater Fisheries", second edition; 47-49. 2004.

[3] Bankole, N.O; Sule, O.D; Okwundu, E.C. and Amadu, M. "Preliminary investigation into the fresh and catch assessment survey of Lake Alau". Annual report to National Institute for freshwater fisheries Pp.22. 1994.

[4] Burton, M.N. The Biology of Clarias gariepinus (Buchell, 1822 ) in lake, sibaya,kwazulu with emphasis on the role as the predator. Unpublished, Department of Zoology Institution for Freshwater Studies, Rhodes University. 1994.

[5] BSMLS, "Borno State Ministry of land survey", Topographical Map. Maiduguri, Nigeria.2002.

[6] CBDA. "A Resettlement Plan for the Lake Alau Dam, Jere bowl scheme". Agricultural survey and background studies report submitted to Chad Basin Development Authority by Askonning Nig, Ltd. 89. 1984.

[7] Dadebo E. "Reproductive Biology and feeding habits of the catfish Clarias gariepinus Burchell (pices: clariidae) in lake Awassa, Ethiopia” SINET. Ethiop. J.Sci.23:231-246. 2000.

[8] Dadebo E. "Filter feeding habits of the African catfish Clarias gariepinus" Burchell, 1822 (pises: Clariidae) in Lake Chamo, Ethiopia. Ethiopia. J. Biol. Sci. 8(1):15-30. 2009.

[9] David DL. Edward A, Adass PA, Jesse C. "Some aspect of water quality and the Biology of Clarias gariepinus in Vimtim Stream, Mubi Adamawa state, Nigeria.” World J. fish mar. Sci. 2(2):129-133. 2010.

[10] EL Gamal Ael-R Ismail NM. "Food composition and feeding habit of some fresh water of fishes in various water systems at Abbassa, Egypt, with special reference to snail transmitting diseases." J. Egypt. Soc. Paracitol. 35(2):637-52. 2005.

[11] Getabu A. "A comparative study on the feeding habits of Oreochromis niloticus in Nyanza Gulf, Lake Victoria and sewage ponds", In: proceeding of the second EEC Regional seminar on Recant Trend of Research on Lake Victoria Fisheries, Kisumu, Kenya, 25-27 September 1992 (Eds. Okemwa E. Wakwabi E and GETABU A). ICIPE, press, Nairobi, Kenya. 1994.

[12] Gwana, Adamu Mohammed; Mshelia, Ngita Hassan; Abdullahi, Mumin Mai; Auwal, Mohammed Shu'aibu; Bagudu, Buhari Yawuri; Mala, B. Mohammed, Abdullahi, Hala Mai; Sadiq, Aji Bukar. "Effects of Domestic Wastes on Water from Shallow - Wells in Moduganari, Nigeria." International Journal of Environmental Monitoring and Analysis. Vol. 2, No. 4, 2014, pp. 185-190. doi: 10.11648/ijema. 20140204.11

[13] Hynes, H.B.N. "The food of water stickle backs (Gastrotesteus aculatus and pygosteus pungitus) with a review of methods used in studies of the food of fishes." J. Eco, 19:36-58. 1950.

[14] Munro. "African Inland water fisheries and environmental processing of fishes" Fisheries Society of Nigeria, Pp. 74. 2001.

[15] Njiru, M; Okeyo-Owuor, J.B; Muchiri, M; Cowx, I.G. "Shift in the food of Nile Tilapia, Oreochromis niloticus (L.) in Lake Victoria, kenya," Afr. J. Ecol. 42: 163-170. 2004.

[16] O'Brien WJ. "Planktivoury by fish"; thrust and parry in pelagia.Pp 3-16. In: predation and indirect effect on aquatic communities W.C. kerfoot \& ASih (eds), University press of new England, Hanover Pp. p.480. 1987.

[17] Omondi R, Yasindi AW. Magana AM. "Spatial and temporal variations of zooplankton in Relation to some environmental factors in lake Baringo, Kenya”. Eger. J. Sci. Technol 11:2950. 2011.

[18] Shalloof, KAS, Khalifa N. "Stomach contents and feeding habit of Oreochromis niloticus (L.) from Abu-Zabal lakes, Egypt. World appl. Sci. J. 6 (1):1-5. 2009.

[19] Royle, W. "Observation on feeding habits of Clarias barrage experimental pond found in food scheme Technology." No.5, Vol. 2.76 - 79. 2001.

[20] Skelton P. "A complete Guide to the freshwater fishes of southern Africa". Halfway House: Southern Book publishers Ltd. 1993.

[21] Stroud, K.A \& Booth, D.J. "Statistical Package", In: Engineering Mathematics.WWW. Palgrave.Com / Stroud, Pal grave, $5^{\text {th }}$ Edition, GB, London; $1130-1139.2001$.

[22] Yalcin S, solak U, solak K. "Stomach Contents of the catfish (Clarias gariepinus Burchell, 1822) in the River Asi, Turkey". Turk.J. zool.25: 461-468. 2001.

[23] Yalcin, S; Solak, k; A.Kyurt, I. "Growth of catfish, Clarias gariepinus (Claridea) in River Asi (Orontes), Turkey." Cybium 26(3): 163-172. 2002.

[24] Zaret, T.M. "Predation of freshwater communities" Yale University press. New Haven. P.187.1980. 